Revista Universo Contábil, ISSN 1809-3337

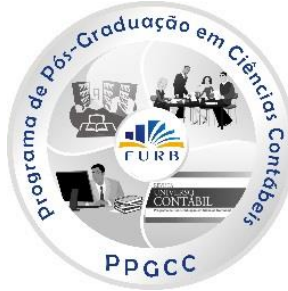

\title{
PRIVATISATION AND MANAGEMENT ACCOUNTING CHANGE: THE DRIVERS OF CHANGES IN A BRAZILIAN ELECTRICITY DISTRIBUTION COMPANY ${ }^{1}$
}

\section{PRIVATIZAÇÃO E MUDANÇAS NA CONTABILIDADE GERENCIAL: OS "DRIVERS" DE MUDANÇAS NUMA DISTRIBUIDORA BRASILEIRA DE ENERGIA ELÉTRICA}

\section{LA PRIVATIZACIÓN Y CAMBIOS EN LA CONTABILIDAD DE GESTIÓN: LOS “DRIVERS" DE LOS CAMBIOS EN LA DISTRIBUCIÓN ELÉCTRICA BRASILEÑA}

\author{
Cláudio de Araújo Wanderley \\ $\mathrm{PhD}$ in Management Accounting - The University of Sheffield \\ Professor do Programa de Pós-Graduação em Contabilidade - UFPE

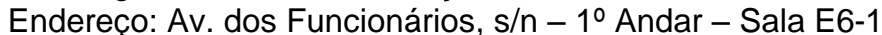 \\ CEP: $50.740-580$ - Recife - PE \\ E-mail: claudio.wanderley@ufpe.br \\ Telefone: (81) 2126-8911
}

\begin{abstract}
The main of this study is to explain the main drivers of the process of management accounting change in a privatised Brazilian electricity distribution company (Electra) by discussing the main factors that affected the management accounting practices of the case study company. This study adopts an interpretive case study as research method to analyse the changes in management accounting that occurred in the case company in a period of 8 years, that is, from 2000 (the privatisation year) to 2007. The drivers of change after the process of privatisation normally come from different sources from inside and outside the organisation. However, in this case study, the pressure from the inside the organisation played an insignificant role as a driver of management accounting change in Electra, as the process of management accounting change was driven by massive pressure from outside the company. The drivers of change in Electra were identified as being: (a) the new regulation; (b) the managerial pressure introduced by the new private owner, that is, the change in the ownership of Electra; (c) the pressure from the electricity sector associations and other distribution companies; and (d) public opinion.
\end{abstract}

Keywords: Management Accounting, Change, Drivers, Privatisation.

\section{RESUMO}

O objetivo desse estudo é explicar os principais drivers para o processo de mudança na contabilidade gerencial de uma empresa Brasileira privatizada de distribuição de energia (Electra), discutindo os fatores intra e inter organizacionais que afetaram as práticas de

\footnotetext{
${ }^{1}$ Artigo recebido em 26.11.2013. Revisado por pares em 15.04.2014. Reformulado em 17.09.204. Recomendado para publicação em 23.09.2014 por Carlos Eduardo Facin Lavarda. Publicado em 30.09.2014. Organização responsável pelo periódico: FURB.
} 
contabilidade gerencial da empresa estudo de caso. Este trabalho é baseado num estudo de caso interpretativo como método de pesquisa para analisar as mudanças na contabilidade gerencial que aconteceram na companhia estudada durante um período de 8 anos, isto é, entre 2000 (o ano de privatização) até 2007. Os drivers de mudanças após o processo de privatização são provenientes de diferentes fontes de dentro e fora da organização. Porém, nesse estudo de caso, as pressões provenientes do ambiente interno da empresa tiveram um papel insignificante no processo de mudança da contabilidade gerencial, pois esse processo em Electra foi causado por uma pressão maciça proveniente de fatores externos à organização. Os drivers de mudanças que foram identificados em Electra foram os seguintes: (a) a nova regulação; $(b)$ a pressão gerencial introduzida pelo novo dono privado, ou seja, a mudança no controle acionário de Electra; (c) a pressão proveniente das associações do setor elétrico e das outras empresas distribuidoras Brasileiras; $e(d)$ opinião pública.

Palavras-chaves: Contabilidade Gerencial, Mudanças, Drivers, Privatização.

\section{RESUMEN}

El objetivo de este trabajo es explicar los principales impulsores de los procesos de cambio en la contabilidad de la gestión de una empresa de distribución eléctrica brasileña privatizada (Electra), discutiendo los factores intra e inter prácticas organizativas que afectaron caso de estudio de contabilidad de gestión de la empresa. Este trabajo se basa en un estudio de caso interpretativo como método de investigación para analizar los cambios en la contabilidad de gestión que han sucedido en la empresa estudiada durante un periodo de 8 años, es decir, entre 2000 (el año de la privatización) por 2007 Motores del cambio después de que el proceso de privatización son de diferentes fuentes dentro y fuera de la organización. Sin embargo, en este estudio de caso, las presiones del ambiente interno de la empresa tuvieron un papel menor en el proceso de cambio de la contabilidad de gestión, ya que este proceso Electra fue causada por la presión masiva de factores externos a la organización. Los impulsores del cambio que se han identificado en Electra fueron los siguientes : (a) la nueva regulación ; ( B ) Presión de gestión presentado por el nuevo propietario privado, es decir, el cambio en el control de Electra ; ( $C$ ) la presión de las asociaciones del sector de la electricidad y otras empresas distribuidoras brasileñas ; $y(d)$ la opinión pública.

Palabras clave: Gestión de Contabilidad, Cambio, Drivers, Privatización.

\section{INTRODUCTION}

The literature about organisational change suggests that companies are unlikely to undertake any change unless significant reasons to do so emerge (HOQUE; ALAM, 2004). Privatisation is directed at changing the basic character and set of beliefs and values of an organisation, because privatisation leads to a new relationship between the organisation and its competitive organisational environment. After a process of privatisation, change can occur for different reasons: deregulation, increased competition, external pressure from financial institutions, public demands, and social, political, and cultural pressures (HOQUE; ALAM, 2004).

The research regarding the process of management accounting change after privatisation can be classified into two main streams. First, there are studies in which the main aim is to demonstrate and explain that accounting can influence and support the process of privatisation by helping the construction of a new organisational culture (see DENT, 1991; SHAOUL, 1997; OGDEN; ANDERSON, 1999; COLE; COOPER, 2006; CRAIG; AMERNIC, 2006). One example of this stream is Ogden's (1995) paper which aims to investigate the ways in which accounting and accounting information contributed to the process of organisational change in the privatised UK water industry. Ogden (1995) focuses on the transformative capacities of 
accounting having to redefine organisational objectives, change the meaning of the organisational activities, and reshape perceptions of what are critical issues for the organisation. The second stream seeks primarily to understand how accounting has been shaped by the process of privatisation (see HOQUE; HOPPER, 1994; 1997; HOQUE; ALAM, 2004; MAJOR; HOPPER, 2004; CONRAD, 2005; UDDIN; TSAMENYI, 2005; TSAMENYI; CULLEN; GONZÁLEZ, 2006).

The studies about management accounting change and privatisation are characterised by the diversity of theories applied by the researchers to understand such a phenomenon. It seems that researchers in this area are using more alternative approaches rather than positivist research. Some scholars have adopted a view that the processes of management accounting transition are sensitive to cultural, political and ethnic issues. According to Hopper et al. (2003), this sort of research is likely to be based upon case studies and have a stronger focus on anthropology and political economy. One example of this kind of research is the paper of Wickramasinghe and Hopper (2005) based upon a longitudinal case study in a textile Mill in a traditional Sinhalese village in Sri Lanka. This article draws on political and economy theory, as well as the modes of production (MOP) theory and cultural anthropology to illustrate that accounting is influenced by, and influences, the organisational and social context within which it operates.

In terms of the contribution of this paper, we seek to expand the literature on privatisation and management accounting change, in particular in developing and less developed countries (LDCs). There are still few studies concerning the effects of privatisation on accounting in developing countries and LDCs (UDDIN; HOPPER, 2001; WICKRAMASINGHE; HOPPER; RATHNASIRI, 2004; HOPPER et al., 2009). According to Uddin and Hopper (2001) and Wickramasinghe, Hopper and Rathnasiri (2004), there are few studies concerning the effects of privatisation on accounting in developing countries. As a consequence, there is a dearth of relevant material for practitioners, policy makers, donor agencies and academics to draw upon. In the context of the Brazilian literature in this issue, there are very few studies dedicated to understanding the relationship between privatisation and management accounting change. Therefore, this investigation aims to fill this gap by providing a comprehensive analysis of the process of privatisation and its impacts on management accounting practices by discussing the drivers of changes in specific Brazilian Distribution Company.

Taking into account this situation, the main aim of this study is to explain and discuss the main drivers of the process of management accounting change in a privatised Brazilian electricity distribution company by articulating the inter and intra organisational factors that affected the management accounting practices of the case study company. Therefore, this study provides empirical evidence on the impacts of privatisation on management accounting systems and the drivers of changes in developing countries using Brazil's electricity sector as a case.

The remainder of the paper is organised into five main sections. First, we briefly review the literature on the drivers of management accounting change. The second section describes the research method and the case study company's characteristics. The following section provides a background of the main management accounting changes that occurred in Electra after the process of privatisation. The next section is the core part of this paper and it aims to discuss the drivers of management accounting change in the case study company. Finally, the conclusion is provided.

\section{DRIVERS OF MANAGEMENT ACCOUNTING CHANGE}

Management accounting change occurs with the creation and introduction of new techniques or with changes in the way managers use management accounting information generated by traditional systems. On one hand, management accounting practices are shaped by the external, as well as by the internal organisational environment. On the other hand, 
management accounting can shape the external and internal environment of the organisation (MOLL, 2003; MOLL; BURNS; MAJOR, 2006). Therefore, management accounting change can be studied in these two ways, that is, the process of management accounting in itself and the impact of management accounting change on the organisational change. In this paper, we focus our analysis on identity the drivers of change and how these factors shaped the process of management accounting change in our case company.

Studies regarding the origins and diffusion of management accounting innovations support the view that management accounting is shaped by the inter and intra organisational environment and management accounting plays an important role in the process of organisational change (PERERA; MCKINNON; HARRISON, 2003; LAPSLEY; WRIGHT, 2004; AX; BJORNENAK, 2007). One such important study by Perera, Mckinnon and Harrison (2003) investigated transfer pricing in a Government Trading Enterprise in Australia. They draw on the Rogers' (1995) diffusion of innovation theory to explain the introduction, abandonment and re-introduction of transfer pricing over a 10-year period. Perera, Mckinnon and Harrison (2003) identify three aspects that can contribute to the study of accounting change which are: (1) the importance of inter-organisational pressures over the process of accounting change. In this Government Trading Enterprise, Perera, Mckinnon and Harrison (2003) found that transfer pricing was introduced as a result of government pressure for the organisation to become more commercialised; (2) the importance of focusing on the subjective values, norms and past experiences of the organisation actors (intra-organisational factors); and (3) the empirical evidence of the paper supports the view that an accounting practice or mechanism can help an organisation shift from one organisational practice to another by generating changes in ways of thinking and behaving and in the climate and the culture of the organisation.

A number of researchers have sought to establish the causes of changes within organisations. For example, Senior (1997, p. 23) identifies three aspects of an organisation's environment that may cause an organisational change, including management accounting: first, the so-called temporal environment, which encompasses the longer-term historical influences, such as 'the changes from an agricultural economy to one based on machines'; second, the external environment which includes factors associated with political/legal, economic, technological and socio-cultural change; third, internal environment, which may include 'change in people (attitudes, beliefs, skills), scale of activities and organisational tasks, organisational strategy and structure, products or services, reward systems or use of technology'.

Many studies have been dedicated to the identification of the causes for change in management accounting. For instance, Innes and Mitchell (1990) carried out seven field studies in the electronics sector about management accounting change. This study identified the following factors: (a) a competitive and dynamic market environment; (b) organisational structure; (c) production technology; (d) product cost structure; (e) management influence; and (f) deteriorating financial performance. More recently, Scapens et al. (2003) carried out an investigation regarding the changing nature of management accounting among UK companies. This study presents four changes in the broader business environment that have had impact on management accounting in recent years: (1) globalisation and customer focus; (2) technological change; (3) changing organisational structures; and (4) fashion and other internal factors, such as 'a feeling at top-level management that change is necessary' and 'changing management information needs' (SCAPENS, et al., 2003, p. 6).

Another study investigating change drivers was carried out by Yazdifar and Tsamenyi (2005). The aim of this paper was to understand the process of management accounting change and the changing roles of management accountants in dependent and independent companies. The findings of this investigation were supported by 279 questionnaires answered by professionally qualified management accountants within CIMA. Yazdifar and Tsamenyi (2005) 
present a ranking of change drivers in management accounting. This ranking in order of importance is the following: (1) information technology; (2) organisational restructuring; (3) customer-oriented initiatives; (4) e-commerce/electronic business; (5) new accounting software; (6) external reporting requirements; (7) new management styles; (8) core competency aims; (9) globalisation; (10) quality-oriented initiatives; (11) new accounting techniques; (12) take-over/merger; (13) external consultants' advice; and (14) production technologies.

From these studies, it can be observed that organisational change, in particular management accounting change has many reasons or drivers for change. Change can occur as a response to external sources, such as market pressures, government laws, consumer expectations, technology, social and political change or internal pressures, such as a change in the power dynamics of the organisation, a change in dealing with a process or behaviour problem, or a change in the size and complexity of the organisation (CARRUTHERS, 1995; GREENWOOD; HININGS, 1996). Changes can also be made in pursuit of organisational strategies to achieve efficiency (LAWRENCE; SHARMA, 2002; TSAMENYI; CULLEN; GONZÁLEZ, 2006). This would suggest that organisations do not always wait for legitimacy to be given, but can make a conscious choice to be perceived as legitimate. Clearly, there are multiple pressures for change that may be interdependent (DAWSON, 1994; DEEGAN, 2002). Dawson (1994, p. 14) gives an example that illustrates this last statement "a push for change in technology may result from competitive pressures or from the exposure of local engineering personnel of the benefits of new developments in capital equipment".

\section{RESEARCH METHOD AND CASE SETTING}

The study adopts an interpretive case study as research method because it can provide a rich description of social, cultural and political contexts (SCAPENS, 2004; 2006; BAXTER; BOEDKER; CHUA, 2008; SCAPENS, 2008). The role of case studies in the interpretive approach, which is based upon a belief that management accounting practices are socially constructed, is to locate practice in its historical, as well as its economic, social and organisational contexts in order to help understand the social structures which shape current practices. In this regard, this study adopts explanatory case study research in order to understand the process of management accounting in a specific privatised electricity distribution company (Electra).

Electra (case study company) is a Brazilian electricity distribution company which was created in the 1960s when two electricity companies were merged to form a state-owned organisation controlled by the company's state government. It is important to highlight that in terms of the Brazilian electricity industry a distribution company has two activities: network function and supply function. Therefore, the Brazilian model is different from some countries, such as the UK where these two activities (distribution and supply) are performed by different organisations.

The case study organisation was privatised in 2000. Electra was acquired by a pool of three organisations: two Brazilian companies and a Spanish organisation. This holding company had taken over two other Brazilian electricity distribution companies before purchasing the case study company. At the time of privatisation, the case study organisation had more than 1.8 million consumers, production of about $7 \mathrm{Gwh}$, and more than 3,000 employees. However, the case company was suffering severe problems, such as commercial deficits and a high level of commercial loss.

The study analyses the changes in management accounting that occurred in Electra in a period of 8 years, that is, from 2000 (the privatisation year) to 2007. Semi-structured and faceto-face interviews constitute the primary method of data collection in this study. In summary, over the period of 6 months, 50 interviews were carried out for a total amount of 64 hours. 25 interviewees worked in the case study company during the privatisation process. Among these 25 interviewees, 16 are still working in Electra, which represents 33\% of the people interviewed 
in this study. Interviews were carried out among 8 different organisations, which are: (a) Electra; (b) Electra's parent company; (c) the holding company of the group; (d) the regulator (ANEEL); (e) Electra's State regulator agency; (f) the association of accountants of the Brazilian electricity sector (ABRACONEE); (g) the Brazilian electricity distribution companies association (ABRADEE); and (h) the Brazilian development bank (BNDES).

Besides generating data from interviews, other sources of data were used to collect evidence. Several documents were collected from Electra, its parent companies, the holding company, the regulator and the Brazilian electricity distribution companies association (ABRADEE). Also, external documentation pertinent to these organisations, such as newspapers and magazine reports, were gathered. It is important to highlight that the researcher had access to corporate systems, such as the performance measurement system and the normative system. The researcher also visited the Electra's historical archive relating to the privatisation process and many documents were analysed, such as the privatisation evaluation report commissioned by BNDES (the Brazilian Developed Bank) and the auction invitation.

In order to identify the drivers of management accounting change in Electra and analyse our data, this study adopt Miles and Huberman's (1994) methods of analysing qualitative data which consists of three complementary flows of activity: data reduction, data display, and conclusion drawing/verification. Data reduction refers to the process of selecting, focusing, simplifying, abstracting, and transforming the data that appear in written-up field notes or transcriptions (MILES; HUBERMAN, 1994). In this paper, data reduction was achieved by writing summaries, coding transcriptions, and writing memos. According to Miles and Huberman (1994), a display is an organised, compressed assembly of information that permits conclusion drawing and action. Matrices, graphs, charts, and networks are examples of displays. Diagrams were prepared to represent the main factors that shaped the management accounting system of the case study organisation (see e.g. figure 1). Finally, the last activity is to draw and verify the conclusions of the case study analysis. This was done by meeting the criteria of plausibility, sturdiness, and confirmability suggested by Miles and Huberman (1994). It is important to highlight that this research used the NVivo version 8.0 (a qualitative data analysis software) to help in the process of data analysis.

\section{MANAGEMENT ACCOUNTING CHANGE IN ELECTRA}

The management accounting changes introduced into Electra after the process of privatisation can be classified into three: budgetary system; performance measurement system; and report system and management accounting utilisation.

The budgetary system became the most important management accounting tool after privatisation. It was regarded as the most important management accounting system that the managers used on day-to-day basis. Electra's Chief Executive Officer (CEO) commented on the importance of budgeting:

Budget is the most important management tool that the company uses to manage and control the company's activities. All the decisions are made based on the budget.

After privatisation, Electra improved the budgetary system by tightening the level of control and by reinforcing the view that the budget is an important system for the company and all members of the organisation have an obligation to achieve budgetary targets. One aspect that was essential to improving the budgeting process was the implementation of an ERP (Enterprise Resource Planning) system. In the case of Electra, the SAP system was implemented in 2002 and the integration of the company's different computer systems facilitated access to the information necessary to prepare and control the budget.

The corporate budget became even more important after the process of Electra's restructuring which took place in mid 2004. As a result of this new management style, the 
financial performance of the organisation, in particular the reduction of operational expenditures and the maximisation of the indicator EBITDA (Earnings before Income Tax, Depreciation and Amortisation), became top priority to the holding company. Although, budgetary information was widely used in the organisation, the budgeting preparation process was based on a top-down approach with limited participation of the company's employees in the process of setting the budgetary targets.

Electra implemented a new performance management system based on the management by objectives (MBO) principles. The MBO establishes that the specific performance measures (objectives) are jointly determined by subordinates and their superiors, progress towards objectives is periodically reviewed, and results are evaluated and rewards are allocated on the basis of this progress. Therefore, the main difference between the previous PMS and the PMS developed after the privatisation is the fact that the latter connects the company's performance with the employees' remuneration through a new bonus scheme which was introduced into the organisation after the privatisation process.

After the privatisation, management accounting information could be accessed by all managers and middle employees, especially information regarding budget and performance measures. The implementation of the SAP system facilitated this change in the way that people used the management accounting information. Information generated from the performance measurement system (PMS) and the budgetary control system became widely used throughout the organisation and the employees started to talk the "accounting language", in particular the performance measures that have impacted on the remuneration system, such as EBITDA and operational expenditures.

The importance of the preparers of Electra's management accounting information, that is, the Accounting Department and the Planning and Control department, changed after the privatisation. The attributes and the role of the management accountants were expanded and, as a consequence, the management accountants had to interact with the other departments of the company. The management accounting area started to be perceived by the other managers as an important source of information to the decision making process. The former Head of the Accounting Department commented:

There was a considerable improvement in terms of economic and financial controls after privatisation. Accounting information started to be seen as a very important source of information in the organisation.

\section{DRIVERS OF CHANGES IN ELECTRA}

This section deals with the main drivers of changes in Electra's management accounting system. The drivers are: (a) the new regulation; (b) the managerial pressure introduced by the new private owner, that is, the change in the ownership of Electra; (c) the pressure from the electricity sector associations and other distribution companies; and (d) public opinion.

\subsection{Regulation}

This sub-section presents and discusses Electra's management accounting change drivers that came from the regulation. These drivers are: (a) the increasing demand for information (operational and financial); and (b) the introduction of the price-cap regulation, that is, the new tariff review process, in particular the concepts of operating expenditures (Opex) based on the Reference Utility methodology, and determination of the regulatory asset base (RAB).

The Brazilian electricity sector became tightly regulated after the reforms and privatisation of the majority of the state owned utilities. From the mid 1990's, the Brazilian government and the electricity industry regulator (ANEEL) has passed numerous laws and guidelines to regulate the new electricity market which is formed by private and state owned companies with different objectives. Before the privatisations and reforms there was a 
department of the Brazilian government (DNAEE - Department of Waters and Electric Energy) that controlled the utilities, but its power and attributions were limited as the majority of the organisations were state owned companies and Eletrobras (the Federal holding company) played an important role in the electricity sector management.

This new regulatory system increased drastically the demand for information that the company have to control and provide to the regulator (INSTITUTO ACENDE BRASIL, 2007). This information is concerned with the operational and financial performance of the organisation. As a result, this put pressure on the company's management and accounting systems to control and report the operational and economic and financial performance of the organisation. There are key operational performance measures that are tightly controlled by the regulator that reflect the quality of the service. An electricity distribution company have to monitor these quality indicators, because if the company has quality indicators below the targets set by the regulator the company will be penalised by paying fines and in severe cases the company can lose the concession (DE BARROS FILHO et al., 2009).

Financial data is an essential source of information to the regulator in order to perform its duties and objectives of sustainability, allocative efficiency, productive efficiency, and equity. This financial information supports the regulatory accounting system which has the aim of supporting the regulator in the process of assessing the financial health of the utility company in order to promote tariff moderateness in defence of the public interest and economic and financial balance of agents which provide energy service. In the context of Electra, its concession contract set the obligation of providing financial information on a regular basis. The regulator also uses the accounting information to inspect the company's activities. ANEEL also requires from Electra three accounting periodic reports. As it can be observed, the range of information required by the regulator is broad and includes financial and non-financial information. These requirements put a lot of pressure on the Electra's accounting system in order to cope with that demand for information. As a consequence, this demand forced the company to change the accounting and management accounting systems.

The price-cap regulation (the Brazilian new regulatory system) introduced after the reforms in the Brazilian electricity sector can be considered as the main driver of management accounting change in Electra that came from the Brazilian government (political and economic level). The tariff methodology applicable to distribution organisations in Brazil is a hybrid system, which encompasses the concept of "service cost" for the cost items of the so-called part A (non-manageable costs), and the price-cap approach for the other cost and capital items of the so-called part B (manageable costs).

The primary objective of economic regulation was to introduce in the performance of a regulated company the effects of competitive pressures (actual and potential) that are typical in competitive markets (SIOSHANSI; PFAFFENBERGER, 2006). Consistent with this objective, the current Brazilian regulatory framework establishes a tariff system for the part B of the tariff based on the price-cap regime, under which services are regulated by price according to economic rules. The objective of this methodology is remodelling public utility services based on the characteristics of private sector activities, which include two principles: efficient service and tariff reasonableness (DE SOUZA; LEGEY, 2008).

According to the Brazilian regulation, there are three types of tariff review processes: (a) the periodic tariff review process (4 years in the case of Electra); (b) the annual tariff adjustment; and (c) the extraordinary tariff review. In terms of the process of organisational and management accounting change in Electra after privatisation, the periodic tariff review process is the one that had impact in these systems. The periodic tariff review is considered the most relevant event in Electra, as during this process the revenue, and as a consequence the profit of the company, is set for a period of 4 years (the price-cap settlement period) (ROCHA; CAMACHO; BRAGANCA, 2007). The periodic review process is applicable to part $\mathrm{B}$ of the 
tariff and it is conducted in two stages: (a) tariff repositioning, which establishes the level of efficient operation costs and the return on capital; and (b) the determination of the $\mathrm{X}$ factor. In terms of management accounting change, the first stage is the most important to be dealt as a driver of change. As stated before, the tariff repositioning calculation adjusts the part B of the company's revenue, which is formed by the controllable costs which are those under the distribution company's control and encompass:

- Operating expenditures (OPEX), which involve the management, commercial, operating and maintenance expenditures which an efficient distributor should incur to supply the market;

- Return on capital, which results from multiplying: (a) the net regulatory asset base (NBRA) by; (b) the opportunity cost to develop the distribution activity in Brazil; and

- Depreciation. The regulatory depreciation is the value to be annually recovered to replace the assets at the end of their operational life, and it is obtained by multiplying: (a) gross regulatory asset base by; (b) the annual depreciation rate.

From the above elements that formed the part B of the tariff, only two items could be influenced by Electra in order to improve company's profit, that is, there were only two items that the company should concentrate its efforts to try to maximise its tariff/revenue in according to the regulation. These two items are: (1) the operating expenditures (OPEX); and (2) the regulatory asset base (RAB). Electra did not have any scope to influence or control the other elements of the calculation of part B of the tariff, as the cost of capital is determined by the regulator; and the annual depreciation rate is also set by the regulator based on the straight-line approach. Therefore, the key elements to Electra in the periodic review process are: the operating expenditures and the regulatory asset base.

The operating expenditures (Opex) were established by the regulator by applying the Reference Utility (or Model utility) methodology. By applying the Reference Utility methodology, the Regulator sought to design a model company which the actual utility (in our case Electra) to compare its performance. As a consequence, this creates an incentive to Electra to operate at lower costs than the standards set by the regulator (SIOSHANSI; PFAFFENBERGER, 2006), as the improvements on the actual costs of the company can be reversed directly to the company's profit during the settlement period. Therefore, this approach sets a benchmark with which Electra will compete, and as a result this methodology creates an incentive to keep costs within recognised limits in order to attain or surpass the expected profitability (TOZZINI, 2008).

The electricity distribution industry can be characterised by being a capital intensive activity (ALEXANDER; HARRIS, 2005), as a result, the remuneration of Electra's investments is a major determinant of the electricity tariff, which accounted for about two thirds of Electra's total costs. Therefore, the regulatory asset base determination is a key aspect for Electra's management system, as Electra should have management and control systems that are able to obtain the maximum value for the regulatory asset base. The regulator determines and approves the composition and value of the regulatory asset base. In this process, two key aspects are essential: (a) determine which types and amount of investments can be included in the regulatory asset base; and (b) how to value these investments for regulatory purpose. For the first point, that is, the establishment of which investments made by the company should be included in the regulatory asset base, ANEEL performed a qualitative analysis of each asset of Electra based on the efficiency and prudent criteria.

In terms of management accounting change, the determination of the asset base was a significant source of pressure to introduce changes in the organisation and its management accounting system. As it demanded the reconciliation between the physical inventory and the 
accounting system information introduced the need to improve the control system of the company, in particular, the budgetary and the performance measurement systems, as well as the reporting system of the organisation. In addition, the determination of the regulatory asset base created the necessity to exchange information between the accounting areas and the engineering areas of the company in order to perform the conciliation between the physical information from the engineering departments and the accounting information. The Manager of the planning and investment department commented:

\begin{abstract}
Now, there is an intensive exchange of information due to the budgeting process and because of the tariff review process. Before, I did not know who the accountant of the company was. Nowadays, the engineers and the accountants have to talk and exchange information for the tariff review process, especially, to determine the regulatory asset base.
\end{abstract}

From the above discussion, it can be observed that these two concepts: the management of the operating expenditures based on the Reference utility approach; and the determination of the regulatory asset base, were essential for the success of the organisation in terms of profitability. This situation goes in line with the study conducted by Pardina, Rapti and Groom (2008) which identified that the determination of the regulatory asset base is one key factor to success of an electricity distribution company, as the fixed assets account for about two thirds of its total assets. The director of planning and control of the holding company also acknowledged the importance of these items for the company's financial success. He stated:

We are focused on knowing how to make profit. How do we make profit? We make profit by managing the remuneration base (regulatory asset base) and the Reference Utility, that is, we have to have a very good control of our costs and we have to know how to invest and register this investment.

To summarise, the price-cap regulation introduced in Brazil was an important driver of management accounting change in Electra, because the tariff review process constituted the principal event in the organisation when the company's revenue is set for a period of 4 years, and as the company operates in private monopoly, where the company does not need to fight for market share, the profit of the company is also determined in this process. Therefore, this change in regulation put pressure on Electra to improve their management accounting systems, in particular, the budgetary and performance measurement systems. In addition, this new regulation forced the operational areas of the company to exchange information with the accounting areas. As a consequence, the importance of the management accounting area increased and the utilisation of management accounting was also affected, as the engineers perceived that the integration of the management accounting information with the operational information was essential to improve the company's performance.

\title{
5.2 Managerial Pressures
}

Electra was also subject to managerial pressures to improve its management accounting systems. Electra was a state-owned and largely bureaucratic company. It had to produce budgets and various reports for both the directors of the company and state. But the systems it used were not integrated into its management process, as before the privatisation, the structures of legitimation and signification (GIDDENS, 1984) were concerned with the engineering aspects of the business. The privatisation of Electra represented the change from a stated owned management style to a private management style with a different set of legitimation and signification structures. After privatisation the legitimation and signification structures were set mainly to achieve the adequate financial performance in a regulated environment, by being profit oriented and cost conscious. 
As a consequence of this shift in the legitimation and signification structures, the new owners of Electra introduced changes in the management accounting system of the organisation in order to improve the quality of the management process. The aim of this change was to create a management accounting system capable of providing information to help the decision making process and controlling the company's activities by providing financial information, as well as being capable of communicating the company's goals to the departments and employees (Jones, 1985)

The managerial drivers of management accounting change came basically from: (a) the introduction of a new business model based on Energia's (the European electricity company part of the holding company) management system, which is based on the Management by Objectives approach. The introduction of this new business model was facilitated by the implantation of an ERP system which also influenced the process of management accounting change; and (b) the restructuring of Electra with increasing focus on financial performance in terms of profitability and cost reduction. This new approach emphasised the control and standardisation of the company's activities. As a result, the internal control system was developed and the company introduced the concepts of ISO and TQM (Total Quality Control) and the Sarbanes-Oxley act (SOX) procedures.

The change in the ownership created pressures on management accounting to change, as the new owner (a group of three private companies) demanded more information to the decision making process, as well as, a system that was able to control the company's operation. This new management style that emerged after privatisation was based on the Management by Objectives principles. As a result, the company started to set targets and objectives for all the departments of Electra and the company needed to control these targets as well. In order to operate this new management system, Electra developed a strategy with two main pillars.

First, the implantation of two new corporate computational systems: the ERP system and the commercial system. The ERP system also had an impact on the process of management accounting change, because this system facilitated the communication between the different areas of the company which had a major impact on the budgeting and performance measurement systems of the organisation (KHOLEIF, ABDEL-KADER; SHERER, 2007). Moreover, the management accounting systems had to be compatible with the ERP system principles, which were created and developed by the holding company in the other two distribution companies of the group. The second pillar of the introduction of the new business model was the change in the management accounting system in itself. That is, the company decided to redesign the management accounting system (budgeting system; performance measuring system and reporting system) in order to be able to use the new business model, as the company needed a management accounting system capable of providing the necessary information to the process of management based on this new private perspective. The former heard of the accounting department pointed out:

\begin{abstract}
At the time of the transition, the main focus was on changing the state-owned culture to a private company culture. The cultural change was possible by implementing the necessary corporative systems. The most important systems were the commercial system to manage the consumers, therefore, the focus move on consumer's satisfaction instead of the state government priorities. Moreover, the company needed control systems to manage the business, that is, a budgeting system. Then the company could make its strategic plan by projecting its cash flows in a period of 30 years which is the concession period.
\end{abstract}

As a consequence of the poor economic and financial performance of Electra between 2000 and 2004, there was a group restructuring. As a result, the new board of director took over and this changed the organisation focus even more towards improving the financial performance of the organisation. This new management team kept the same principles of the 
previous business model based on the Management by Objective approach, but their focus was on achieving the economic and financial targets of the organisation. This new strategy was translated in terms of numbers (accounting figures). A similar approach was used by General Electric in the case of the Nuovo Pignone acquisition described by Busco, et al. (2005). As a consequence, the management accounting system was driven to introduce changes in order to cope with this new demand, in particular the budgeting system was the one that gained the status of the most important system in term of management and control in the organisation after the restructuring process. In the same vein, the company introduced a range of initiatives to improve the internal control system, especially with the implantation of the ISO/TQM and the Sarbanes Oxley act procedures. These measures also helped to shape the management accounting system in Electra, because the effort to modify the internal control systems and standardise company's procedures forced changes in management accounting in order to adapt to this new requirements.

\subsection{Electricity Industry and Associations}

Having discussed the two major drivers of management accounting change in Electra, this sub-section explores the influence of the electricity sector associations and other distribution companies on Electra, after the process of privatisation. The influence of those entities was not as broad as the influence of the regulator had on shaping management accounting systems in Electra, as those entities did not have the coercive power that the regulator had over Electra. However, the electricity associations and other distributions companies had to some extent influenced the process of management accounting change in Electra, but this influence can be considered small, especially compared with the regulator pressures.

The Brazilian electricity distribution sector can be considered as an open sector in terms of accessing and exchanging information regarding the performance and management practices of the distribution utilities. This is possible, because the companies operate in a regime of concessions by regions with captive consumers which can be seen as a sort of private monopoly. This peculiarity of the Brazilian electricity distribution sector facilitated the process of isomorphism (DIMAGGIO; POWELL, 1983; 1991), which refers to the adaptation of an institutional practice by an organisation. Therefore, the openness of the sector can facilitate the advent of mimetic isomorphism which occurs when an organisation imitates certain practices of other organisations which it perceives to be more successful. Dillard, Rigsby and Goodman (2004) also talk about this mimetic process, they state that there are two types of organisations the innovators or late adopters. Innovators are those organisations developing new organisational practices, while late adopters are those companies that adopt the practices of innovator organisations. As the Brazilian electricity distribution sector is a natural monopoly, the communication between innovator organisations and late adopters are facilitated and enhanced. In the case of Electra, this exchange of information is illustrated by the statement made by Electra's CEO regarding visiting and exchanging knowledge with another distribution company in Brazil:

We have decided to upgrade your ERP system and we want to add other modules in that system, as well (...). Two months ago, we went to CEMIG (another Brazilian company) to see its ERP systems and the modules that we want to buy. We talked to the CEMIG managers about the benefits of the system and the process of implementation (...). The sector is really open and we can exchange experiences with other companies. We do not need to reinvent the wheel.

Another important entity in the process of management accounting change in Electra was ABRADEE (The Brazilian Electricity Distribution Companies Association). Two programmes developed by this association had to some extent influenced the management 
accounting practices in Electra after the privatisation. These two initiatives are: (a) the annual ABRADEE reward; and (b) ABRADEE benchmark programmes. These two programmes aim to influence the distribution companies' management systems in accordance to the ABRADEE's policies for the development of the electricity sector by providing studies, guidelines and evaluating the companies' management systems. In terms of the isomorphism concept (DIMAGGIO; POWELL, 1983; 1991), this kind of influence can be considered as a source of normative isomorphism (DACIN, 1997) which stems from pressures form professional groups and associations. The Head of the Planning and Control Department commented about ABRADEE's influence:

\begin{abstract}
ABRADEE helps, because it has the best practices base and the management information system. The electricity sector is very open, we can visit other companies to see what they are using and doing (...) We use the ABRADEE data base and we also visit other companies to see what is going on. We also use the performance indicators to compare our performance. So, the electricity sector is extremely open.
\end{abstract}

One Manager of the Planning and Control Department pointed out that the company used the information provided by ABRADEE award evaluation report to improve the management systems of the company:

The company uses the ABRADEE model as a reference for the management of the company (...). We also use the ABRADEE award evaluation report to identify our problem and improve the management systems.

From the discussion above, it can be observed that the other distribution companies' practices and the work of the ABRADEE influenced the evolution of the management accounting systems in Electra after the privatisation, but it is important to highlight that this influence was indirect and much less strong than the influence of the regulation in process of management accounting change.

\title{
5.4 Public Opinion
}

Since the beginning of the discussion about the process of privatisation of the Brazilian electricity utilities, the issue was very controversial in Brazil, which led to conflicts between different entities of the society and political parties in Brazil (MOTA, 2003). The neo-liberal ideas introduced by the Fernando Henrique Cardoso government (1995-2002) were very controversial because it was a profound shift on the Brazilian economic development model, which was based on government interventions and investments. In addition, the privatisation of the Brazilian distribution companies were characterised by regional political interests, as each Brazilian state had different political background and priorities (ARAUJO; OLIVEIRA, 2005; ARAUJO, 2006). This environment caused among some segments of the society and consumers scepticism about the importance and benefits of the privatisation in terms of the quality and expansion of the electricity service, as well as the tariff affordability. As a result, those agents put pressure on the privatised companies to improve the electric and management systems.

This pressure on the recent privatised companies increased due to the 2001 electricity crisis, when the consumers were obliged to reduce the consumption in about $20 \%$ for a period of about 1 year. Another huge problem of the Brazilian electricity sector for the society and consumers was the fact that the electricity tariff has increased considerably after the start of the privatisation process in Brazil (ARAUJO et al., 2008a). The electricity tariff has risen faster than inflation, especially after 1999.

Therefore, there was a problem concerning consumer tariff readjustments. However, during the first years of the privatisation process, the tariffs were stable. The problem started after the 1999 Real (Brazilian currency) devaluation. As a consequence, the electricity tariff 
started to grow much faster than the consumer price index, leading to discontentment, pressures on the budget of poorer households, and an increase in defaulting and other commercial losses (ARAUJO et al., 2008b). The electricity tariff increased 398\% from 1994 to 2007, while the IGP-M and IPCA indexes increased $236 \%$ and $164 \%$, respectively (SANTOS et al., 2008).

In addition to the increase in the consumers' tariff, the profit of the electricity companies in Brazil increased considerably in order to remunerate the new private owners. According to Santos, et al. (2008), the electricity tariff increased five times after privatisation and the dividends of the electricity companies rose at that same proportion after privatisation. In the context of the case study company (Electra), the profit of the organisation rose considerably since the privatisation, in particular after 2005 which was the year that the first tariff review was carried out in Electra. The first tariff review in Electra was very controversial and to some extant damaged the image of the company and increased the pressure over Electra to provide better services.

From the discussion above, it can be observed that the Brazilian distribution companies have been facing an increasing pressure from the society and public opinion to overcome the flaws and problems of the Brazilian Electricity sector, which was developed on ad hoc decisions (ARAUJO, 2006). It can be summarised that the sources of pressure from the public opinion came from the following issues: (a) the ideological opposition to privatisation from some segments of the society and political parties; (b) the 2001 electricity crisis that exposed the flaws of the Brazilian electricity model created after the privatisation; (c) The increase in the electricity tariff; and (d) the increase in the distribution companies' profitability, especially after 2002.

The Brazilian distribution companies tried to justify the increase in the tariffs and privatisation by pointing out the quality of the service is better and that more people have access to electricity, after privatisation. These indicators improved by about $40 \%$ in this period. The percentage of the Brazilian population with the electricity service also increased from $93.3 \%$ in 1997 to $97.7 \%$ in 2007 (ABRADEE, 2008). In addition, the distribution companies tried to show that the companies are better manage after privatisation, as they are adopting a range of management tools, such as the Balanced Scorecard and ISO certification (ABRADEE, 2009). Moreover, the distribution companies tried to portray that their companies are more accountable with the introduction of strong regulatory framework, corporate governance principles and corporate social responsibility (CSR) models (ABRADEE, 2007; 2008).

In the context of Electra, the company suffered the same pressure from the public opinion and society that other distribution companies suffered. However, in the case of Electra these pressures were enhanced by the problematic tariff review process, when some of consumers and media believed that the company used unfair mechanisms to improve the company's profit. Electra used the same rhetoric of the other distribution companies to justify the privatisation by pointing out the quality gains after the privatisation and the expansion of the system that is universal since the end of 2008. The company also engaged a range of corporate social responsibility initiatives, in particular, regarding the impact of its business on the environment.

It is advocated in this section that these pressures also had an impact on the process of management accounting change in Electra, as one of the main concerns of the organisation was improving its image on the society to justify its privatisation and the increase in the electricity tariff and company's profit. One way to improve the company's image was to demonstrate that the company had implemented a better management system after privatisation, which was able to provide a better service and eliminate the inefficiencies of a state-owned administration. This concern about the image of the company and its impact on the management and accounting systems is visible in the following statement by the Head of the Management Department of Electra: 
Actually, we need (...) it is a popular saying 'we do not need to be honest, we should show that we are honest'. So, nowadays, there are a range of instruments and systems that we should show that we are using to get recognition from the market and society. It is crucial to improve the company's image (...). So, it is important to demonstrate to our employees and the society that Electra has a modern business model and we have been gotten good results, because the company is going in the right direction with the adequate management systems and tools.

\subsection{Summary of the Drivers of Change}

This section dealt with the main drivers of changes in Electra's management accounting system, they are: (a) the new regulation; (b) the managerial pressure introduced by the new private owner; (c) the pressure from the electricity sector associations and other distribution companies; and (d) public opinion. Figure 1 depicts the drivers of management accounting change in Electra. The arrows from the regulation and managerial pressures boxes are thicker than the arrows from the electricity industry and associations, and public opinion boxes to demonstrate that the changes in regulation combined with the new ownership were the main drivers of management accounting change in Electra.

Figure 1 - Electra's Drivers of Management Accounting Change

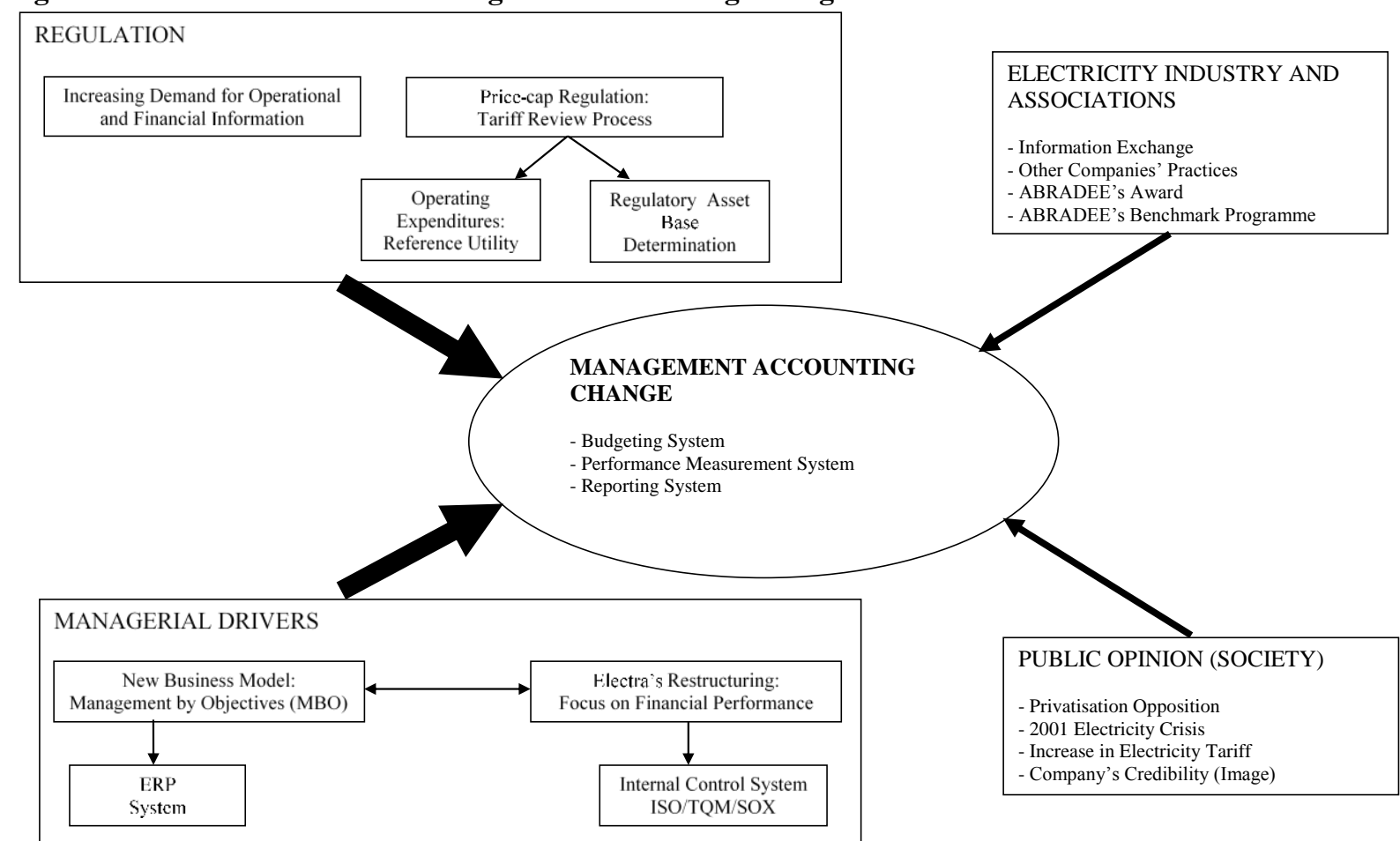

\section{CONCLUSION}

This paper aimed to identity and discuss the drivers of management accounting change in Electra. The drivers of change after the process of privatisation normally come from different sources from inside and outside the organisation ( TSAMENYI; CULLEN; GONZÁLEZ, 2006; JOHANSSON; SIVERBO, 2009). However, in this case study, the pressure from the inside the organisation played an insignificant role as a driver of management accounting change in Electra, as the process of management accounting change was driven by massive pressure from outside the company. The drivers of change in Electra were identified as being: (a) the new regulation; (b) the managerial pressure introduced by the new private owner, that is, the change in the ownership of Electra; (c) the pressure from the electricity sector associations and other distribution companies; and (d) public opinion.

Among these drivers of change, the changes in regulation and the change in ownership from stated-owned company to a private company were the main forces to introduce 
management accounting changes in Electra. The regulator as source of coercive isomorphism (DIMAGGIO; POWELL, 1991) played an important role in the process of change in Electra. The price-cap regulation introduced in Brazil was an important driver of management accounting change in Electra, because the tariff review process constituted the principal event in the organisation when the company's revenue is set for a period of 4 years. Therefore, this change in the regulatory system put pressure on Electra to improve its management accounting systems. Moreover, this new regulation forced the operational areas of the company to exchange information with the accounting areas. As a consequence, the importance of the management accounting area increased and the utilisation of management accounting was also affected, as the engineers perceived that the integration of the management accounting information with the operational information was essential to improve the company's performance.

The change in ownership was another important driver of change in Electra, as the new management accounting systems were coercively imposed by the holding company in order to improve the quality of the management process. The aim of this change was to create a management accounting system capable of providing information to support the new management style that emerged after the privatisation which was based on Management by Objective principles. Therefore, the view about the management accounting system was that this system had to support the managerial process of the organisation by helping the decision making process and controlling the company's activities. As a consequence, management accounting should provide financial information to the decision making process, as well as being capable of communicating the company's goals to the departments and employees.

This paper also provides evidence about the impact of regulation and other macro policies on the accounting practices and systems of an electricity distribution company. As a consequence, this study concentrates on the micro level of analysis of the relationship between regulation and management accounting systems. This type of research is not common in the regulatory accounting literature ( PARDINA; RAPTI; GROOM , 2008). Normally, the research about regulatory accounting focuses on the macro level of analysis by studying the impact of regulation on the whole electricity sector; as a result this kind of study loses the richness that can be obtained by a detailed case study in a single company. As a result, our study provides useful information that can support the regulator to create new regulations or to improve the existing regulations.

\section{REFERENCES}

ABRADEE. Programa De Benchmarking Fipe - Abradee. São Paulo: Abradee. 2007

. Manual Do Prêmio Abradee 2008. Rio De Janeiro: Abradee. 2008

Associação Brasileira De Distribuidores De Energia Elétrica, Disponível Em: $\langle\mathrm{Http}: / / \mathrm{Www}$. Abradee.Org.Br $\rangle .2009$.

ALEXANDER, I. E C. Harris. The Regulation Of Investment In Utilities: Concepts And Applications. Washington, Dc: World Bank. 2005. Ix, 140 P. (World Bank Working Paper, No. 521726-5878) Doi: 10.1596/978-0-8213-6152-8

ARAUJO, J. L. R. H. D. The Case Of Brazil: Reform By Trial And Error? In: F. P. Sioshansi E W. Pfaffenberger (Ed.). Electricity Market Reform: An International Perspective. Amsterdam; London: Elsevier, 2006. p.565-594 Doi: 10.1016/J.Tej.2008.02.001

ARAUJO, J. L. R. H. D.; COSTA, A. M. D. A. D.; CORREIA, T.; MELO, E. Energy Contracting In Brazil And Electricity Prices. International Journal Of Energy Sector Management, v.2, n.1, p.36-51. 2008a. Doi: 10.1108/17506220810859088 
Reform Of The Reforms In Brazil: Problems And Solutions. In: F. P. Sioshansi (Ed.). Competitive Electricity Markets: Design, Implementation, Performance. Amsterdam; London: Elsevier, 2008b. Reform Of The Reforms In Brazil: Problems And Solutions, P.543572

ARAUjO, J. L. R. H. D.; OlIVEIRA, E A. D.. Diálogos Da Energia: Reflexões Sobre A Última Década, 1994-2004. Rio De Janeiro: 7 Letras. 2005

AX, C.; BJORNENAK, T. Management Accounting Innovations: Origins and Diffusion. In: HOPPER, Trevor; NORTHCOTT, Deryl; SCAPENS, Robert (Ed.). Issues in management accounting. Pearson education, 2007. Doi: 10.1016/J.Mar.2004.12.002

BAXTER, J.; BOEDKER, C.; CHUA, W. F. The future (s) of interpretive accounting research - a polyphonic response from beyond the metropolis. Critical Perspectives on Accounting, v. 19, n. 6, p. 880-886, 2008. Doi: 10.1016/J.Cpa.2007.02.009

BUSCO, C.; RICCABONI, A.; SCAPENS, R. Accounting, Learning And Cultural Integration. In: N. B. Macintosh E T. Hopper (Ed.). Accounting, The Social And The Political: Classics, Contemporary And Beyond. Amsterdam ; Oxford: Elsevier, 2005. p.285-291

CARRUTHERS, B. G. Accounting, Ambiguity, And The New Institutionalism. Accounting, Organizations And Society, v.20, n.4, p.313-328. 1995. Doi: 10.1016/0361-3682(95)96795-6

COLE, B.; COOPER, C. Deskilling In The 21st Century: The Case Of Rail Privatisation. Critical Perspectives On Accounting, v.17, n.5, p.601-625. 2006. Doi: 10.1016/J.Cpa.2003.06.011

Conrad, L. A Structuration Analysis Of Accounting Systems And Systems Of Accountability In The Privatised Gas Industry. Critical Perspectives On Accounting, v.16, n.1, p.1-26. 2005. Doi: 10.1016/S1045-2354(02)00212-5

CRAIG, R.; AMERNIC, J. The Mobilization Of Accounting In Preening For Privatization. Accounting, Auditing \& Accountability Journal, v.19, n.1, p.82-95. 2006. Doi: $10.1108 / 09513570610651957$

DACIN, M. T. Isomorphism In Context: The Power And Prescription Of Institutional Norms. The Academy Of Management Journal, v.40, n.1, p.46-81. 1997. Doi: 10.2307/257020

DAWSON, P. Organizational Change: A Processual Approach. London: Paul Chapman. 1994. 211p. (Human Resource Management Series) Doi: 10.1080/08109029508631986.

DE BARROS FILHO, J. P.; DA SILVA, C. F. D.; MÉLO, M. A. do N.; DE MEDEIROS, D. D. Evaluating Perceived Quality Of Celpe Service: A Brazilian Power Company Case Study. Energy Policy, v.37, n.4, p.1571-1579. 2009. Doi: 10.1016/J.Enpol.2008.12.024

DE SOUZA, F. C.; LEGEY, L. F. L. Brazilian Electricity Market Structure And Risk Management Tools. Power And Energy Society General Meeting - Conversion And Delivery Of Electrical Energy In The 21st Century, 2008 Ieee, 2008. p. 1-8. Doi: 10.1109/Pes.2008.4596313

DEEGAN, C. Introduction: The Legitimising Effect Of Social And Environmental Disclosures - A Theoretical Foundation. Accounting, Auditing \& Accountability Journal, v.15, n.3. 2002. Doi: $10.1108 / 09513570210435852$

DENT, J. F. Accounting And Organizational Cultures: A Field Study Of The Emergence Of A New Organizational Reality. Accounting, Organizations And Society, v.16, n.8, p.705-732. 1991. Doi: 10.1016/0361-3682(91)90021-6 
DILLARD, J. F.; RIGSBY, J. T.; GOODMAN, C. The making and remaking of organization context: duality and the institutionalization process. Accounting, Auditing \& Accountability Journal, v. 17, n. 4, p. 506-542, 2004. Doi: 10.1108/09513570410554542

DIMAGGIO, P. J.; POWELL, W. W. The Iron Cage Revisited: Institutional Isomorphism And Collective Rationality In Organizational Fields. American Sociological Review, v.48, n.2, p.147-160. 1983. Doi: 10.2307/2095101.

The Iron Cage Revisited: Institutional Isomorphism And Collective Rationality In Organizational Fields. In: W. W. Powell and P. J. Dimaggio (Ed.). The New Institutionalism In Organizational Analysis. Chicago, Ill. ; London: University Of Chicago Press, 1991. p.6382. Doi:10.2307/2095101.

Giddens, A. The Constitution Of Society. Cambridge: Polity Press. 1984

GREENWOOD, R.; HININGS; C. R. Understanding Radical Organizational Change: Bringing Together The Old And The New Institutionalism. The Academy Of Management Review, v.21, n.4, p.1022-1054. 1996. Doi:10.5465/Amr.1996.9704071862

HOPPER, T.; TSAMENYI, M.; UDDIN, S.; WICKRAMASINGHE, D. Management Accounting In Less Developed Countries: What Is Known And Needs Knowing. Accounting, $\begin{array}{lllllll}\text { Auditing } \& \text { Accountability Journal, } & \text { v.22, } & \text { n.3, } & \text { p.469-514. }\end{array}$ Doi: $10.1108 / 09513570910945697$

HOPPER, T.; WICKRAMASINGHE, D.; TSAMENYI, M.; UDDIN, S. The State They're In. Financial Managment, v.June, p.14-19. 2003.

HOQUE, Z.; ALAM, M. Privatization, Management Accounting Change, And Cultural Values In A Developing Country: A Case Study From Bangladesh. In: T. Hopper and Z. Hoque (Ed.). Accounting And Accountability In Emerging And Transition Economies: Research In Accounting In Emerging Economies. Supplement: 2. Amsterdam: Elsevier, 2004. p.441-466

HOQUE, Z.; HOPPER, T. Rationality, Accounting And Politics: A Case Study Of Management Control In A Bangladeshi Jute Mill. Management Accounting Research, v.5, n.1, p.5-30. 1994. Doi: 10.1006/Mare.1994.1002

Political And Industrial Relations Turbulence, Competition And Budgeting In The Nationalised Jute Mill Of Bangladesh. Accounting And Business Research, v.27, n.2, p.125147. 1997. Doi: 10.1080/00014788.1997.9729539

INNES, J.; MITCHELL, F. The Process Of Change In Management Accounting: Some Field Study Evidence Management Accounting Research, v.1, n.1, p.3-19. 1990. Doi: 10.1016/S1044-5005(90)70042-X

INSTITUTO ACENDE BRASIL. Política Tarifária e Regulação Por Incentivos. Caderno De Política Tarifária, v.1, Outubro. 2007.

JOHANSSON, T.; SIVERBO, S.. Why Is Research On Management Accounting Change Not Explicitly Evolutionary? Taking The Next Step In The Conceptualisation Of Management Accounting Change. Management Accounting Research, v.20, n.2, p.146-162. 2009. Doi: $10.1108 / 11766090610670631$

JONES, C. S. An Empirical Study Of The Role Of Management Accounting Systems Following Takeover Or Merger. Accounting, Organizations And Society, v.10, n.2, p.177-200. 1985. Doi: 10.1016/0361-3682(85)90015-7

KHOLEIF, A.; ABDEL-KADER, M.; SHERER, M. ERP customization failure: Institutionalized accounting practices, power relations and market forces. Journal of 
Accounting \& Organizational Change, $\quad$ v. $\quad 3, \quad$ n. $\quad 3, \quad$ p. 250-269, 2007. Doi: $10.1108 / 18325910710820292$.

LAPSLEY, I.; WRIGHT, E. The Diffusion Of Management Accounting Innovations In The Public Sector: A Research Agenda. Management Accounting Research, v.15, n.3, p.355-374. 2004. Doi: 10.1016/J.Mar.2003.12.007

LAWRENCE, S.; SHARMA, U. Commodification Of Education And Academic Labour-Using The Balanced Scorecard In A University Setting. Critical Perspectives On Accounting, v.13, n.5-6, p.661-677. 2002. Doi: 10.1006/Cpac.2002.0562

MAJOR, M.; HOPPER, T.. Extending New Institutional Theory: Regulation And ActivityBased Costing In The Portuguese Telecommunications Industry. The Fourth Asia Pacific Interdisciplinary Research In Accounting Conference. Singapore: 4-6 July 20042004.

MILES, M.B; HUBERMAN, A.M. Qualitative Data Analysis: An Expanded Sourcebook. Thousand Oaks, Calif.; London: Sage, 1994.

MOLL, J. Organisational Change And Accounting Control Systems At An Australian University: A Longitudinal Case Study. Umpublished Phd Thesis, Griffith University, 2003.

MOLL, J.; BURNS, J.; MAJOR, M. Institutional Theory. In: Z. Hoque (Ed.). Methodological Issues In Accounting Research: Theories, Methods And Issues. London: Spiramus Press, 2006. Institutional Theory, p.183-205

MOTA, R. L. The Restructuring And Privatisation Of Electricity Distribution And Supply Business In Brazil: A Social Cost-Benefit Analysis. Cambridge Working Papers In Economics N.Dae 0309. 2003.

OGDEN, S. G.; ANDERSON, F. The Role Of Accounting In Organisational Change: Promoting Performance Improvements In The Privatised Uk Water Industry. Critical Perspectives On Accounting, v.10, n.1, p.91-124. 1999. Doi: 10.1006/Cpac.1998.0200

PARDINA, M. R.; RAPTI, R. S.; GROOM, E. Accounting For Infrastructure Regulation: An Introduction. Washington, Dc: World Bank. 2008. Xiii, 222 P.

PERERA, S.; MCKINNON, J. L.; HARRISON, G. L. Diffusion Of Transfer Pricing Innovation In The Context Of Commercialization--A Longitudinal Case Study Of A Government Trading Enterprise. Management Accounting Research, v.14, n.2, p.140-164. 2003. Doi: 10.1016/S1044-5005(03)00023-4.

ROCHA, K.; CAMACHO, F.; BRAGANCA, G. Return On Capital Of Brazilian Electricity Distributors: A Comparative Analysis. Energy Policy, v.35, n.4, p.2526-2537. 2007. Doi: 10.1016/J.Enpol.2006.09.012.

ROGERS, E. M. Diffusion Of Innovations. New York: The Free Press. 1995

SANTOS, G. A. G. D.; BARBOSA, E.; SILVA, J. F.; ABREU, R. D. S. D. Por Que As Tarifas Foram Para Os Céus? Propostas Para O Setor Elétrico Brasileiro. Revista do BNDES, v.14, n.29, Jun, p.435-474. 2008.

SCAPENS, R. W. Doing Case Study Research. In: HUMPHREY, C.; LEE, B. (Ed.). The Real Life Guide To Accounting Research: A Behind-The-Scenes View Of Using Qualitative Research Methods. Amsterdam ; Boston: Elsevier, 2004. Doing Case Study Research, p.257279

Understanding Management Accounting Practices: A Personal Journey. The British Accounting Review, v.38, n.1, p.1-30. 2006. Doi: 10.1016/J.Bar.2005.10.002. 
Seeking The Relevance Of Interpretive Research: A Contribution To The Polyphonic

Debate. Critical Perspectives On Accounting, v.19, n.6, p.915-919. 2008. Doi: 10.1016/J.Cpa.2007.02.006.

SCAPENS, R. W.; EZZAMEL, M.; BURNS, J.; BALDVINSDOTTIR, G. The Future Direction Of Uk Management Accounting Practice. Amsterdam ; London: Elsevier. 2003. Ix, $46 \mathrm{p} \mathrm{p}$.

SENIOR, B. Organisational Change. London: Pitman. 1997. Ix, 321p P.

SHAOUL, J. The Power Of Accounting: Reflecting On Water Privatization? Accounting, Auditing \& Accountability Journal, v.10, n.3, p.382-405. $1997 . \quad$ Doi: $10.1108 / 09513579710178124$

SIOSHANSI, F. P.; PFAFFENBERGER, W. Electricity Market Reform: An International Perspective. Amsterdam; London: Elsevier. 2006. Xxix, 656 P. (Elsevier Global Energy Policy And Economics Series) Doi: 10.1016/J.Enpol.2006.08.001.

TOZZINI, S. Benchmark Regulation In Brazil: Potencial Strategic Implications For Electricity Distribution Utilities. International Journal Of Energy Sector Management, v.2, n.1, p.5274. 2008. Doi: $10.1108 / 17506220810859097$

TSAMENYI, M.; CULLEN, J.; GONZÁLEZ, J. M. G. Changes In Accounting And Financial Information System In A Spanish Electricity Company: A New Institutional Theory Analysis. Management Accounting Research, v.17, n.4, p.409-432. 2006. Doi: 10.1016/J.Mar.2006.02.002.

UDDIN, S.; TSAMENYI, E M. A Bangladesh Soap Opera: Privatisation, Accounting, And Regimes Of Control In A Less Developed Country. Accounting,Organizations And Society, V.26, N.7-8, P.643-672. 2001. Doi: 10.1016/S0361-3682(01)00019-8

UDDIN, S.; TSAMENYI, E M. Public Sector Reforms And The Public Interest: A Case Study Of Accounting Control Changes And Performance Monitoring In A Ghanaian State-Owned Enterprise. Accounting, Auditing \& Accountability Journal, v.18, n.5, p.648-674. 2005. Doi: $10.1108 / 09513570510620493$

WICKRAMASINGHE, D.; HOPPER T. A Cultural Political Economy Of Management Accounting Controls: A Case Study Of A Textile Mill In A Traditional Sinhalese Village. Critical Perspectives On Accounting, v.16, n.4, p.473-503. 2005. Doi: 10.1016/J.Cpa.2003.07.001

WICKRAMASINGHE, D.; HOPPER, T.; RATHNASIRI, C. Japanese Cost Management Meets Sri Lankan Politics: Disappearance And Reappearance Of Bureaucratic Management Controls In A Privatised Utility. Accounting, Auditing \& Accountability Journal, v.17, n.1, p.85-120. 2004. Doi: 10.1108/09513570410525229

YAZDIFAR, H.; TSAMENYI, E M.. Management Accounting Change And The Changing Roles Of Management Accountants: A Comparative Analysis Between Dependent And Independent Organizations. Journal Of Accounting \& Organizational Change, v.1, n.2, p.180 - 198. 2005. Doi: 10.1108/18325910510635353 